\title{
Src Kinase-Associated Phosphoprotein 1
}

National Cancer Institute

\section{Source}

National Cancer Institute. Src Kinase-Associated Phosphoprotein 1. NCI Thesaurus. Code C124239.

Src kinase-associated phosphoprotein 1 (359 aa, $41 \mathrm{kDa}$ ) is encoded by the human SKAP1 gene. This protein plays a role in integrin clustering following T-cell receptor signaling. 